\title{
The Collapse of Global Governance: When the U.S. Leaves the Joint Comprehensive Plan of Action (JCPOA)
}

\author{
Yusa Djuyandi *, (D), Shafa Ghaisani Salsabila Brahmantika iD, and \\ Bima Riandy Tarigan
}

Department of Political Science, Faculty of Social and Political Sciences,

Universitas Padjadjaran, 45363, Jatinangor, West Java Province, Indonesia

* Corresponding Author: yusa.djuyandi@unpad.ac.id

\section{ARTICLE INFO}

\section{Publication Info:}

Literature Review

How to cite:

Djuyandi, Y., Brahmantika, S. G.

S., E Tarigan, B. R. (2021). The

Collapse of Global Governance:

When the U.S. Leaves the Joint

Comprehensive Plan of Action

(JCPOA). Society, 9(2), 504-521.

DOI: $10.33019 /$ society.v9i2.304

Copyright (C) 2021. Owned by Author(s), published by Society

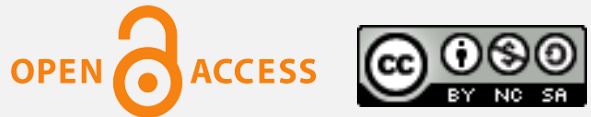

This is an open-access article.

License: Attribution-

NonCommercial-ShareAlike (CC BY-NC-SA)

Received: January 30, 2021;

Accepted: June 29, 2021;

Published: December 31, 2021;

\section{ABSTRACT}

Global Governance encompasses the world's political activities and the management of issues and phenomena that occurred on a nation-state, involving contributions from regional to the international environment. In the global security sector, there are numerous efforts carried out by a country to counter such external threats that can cause destabilization. Nonproliferation and nuclear developments for peace are such issues of the global defense-security concern. The attempts to control and ensure the use of nuclear has been carried out by enacting international law, resolutions, and multilateral agreements. The Joint Comprehensive Plan of Action (JCPOA) is one kind. Influencing the world's security, politics, and economy, the existence of JCPOA began to be disrupted since the United States (U.S.) withdrawal as one of the parties that initially signed the agreement. This research aims to analyze The Collapse of Global Governance: When the U.S. Leaves the Joint Comprehensive Plan of Action (JCPOA). This research used a qualitative method with analysis based on secondary data, validated by the triangulation technique in this qualitative study. The analytical procedure uses secondary data from journals, media, and literature related to the Iran nuclear agreement and previous analyses discussing the U.S. exit from the JCPOA agreement. The analysis technique performs by arranging the data sequence, organizing the data into a pattern, category, and basic description. This research has found that Global Governance has fundamental weaknesses in its application. Through an analysis of the U.S. exit from the Iran nuclear agreement, it can be said that the reins of control are in the hands of the U.S. The Trump administration's policy on behalf of the U.S. to leave JCPOA to thwart the achievement 
of Global Governance and significantly affects the multinational economic, political, and security order. The implementation of Global Governance and the issues also raised based on the interests of the superpowers.

Keywords: Global Governance; JCPOA; Non-Proliferation; Nuclear; United States

\section{Introduction}

Developing strength through military and security supporting instruments, including having power through nuclear energy, is the quest and goal of many countries. However, to avoid the development and use of nuclear fuel for weapons of mass destruction, which due to its very high destructive factor, the international system then formed an agreement called the Treaty on the Non-Proliferation of Nuclear Weapons (NPT), which has been in effect since March 5, 1970. This treaty aims to limit ownership of nuclear weapons, namely in terms of commitments for nuclear disarmament, non-proliferation, and the right to use nuclear fuel for peaceful purposes (Kementerian Luar Negeri Republik Indonesia, 2019).

Iran's nuclear development dates back to the 1950s, when Iranian leaders received technical assistance under the U.S. program, Atoms for Peace, which produced its first nuclear reactor in November 1967 (Nuclear Threat Initiative, 2020). Then in 1958, Iran became a member of the International Atomic Energy Agency (IAEA) and co-signed the Treaty on the Non-Proliferation of Nuclear Weapons (NPT) in 1970. However, the 1979 Iranian Revolution and the attack on the Embassy of United States (U.S.) in Tehran caused relations to become inadequate between Iran and Western countries and impacted the discontinuation of the Iranian nuclear project, which was only resumed in 2002 (Arms Control Association, 2020).

Apart from escalating the dispute between Western countries with Iran, the international system has produced several resolutions and sanctions for Iran, such as those imposed by the U.S., the U.N. Security Council, and the European Union (Mardani \& Hooshmand, 2016, p. 70). In June 2006, the United States, the United Kingdom, France, China, Russia, and Germany as the permanent members of the United Nations Security Council plus Germany, which was later referred to as the $\mathrm{P} 5+1$ together with the European Union, began proposing a framework agreement with Iran to halt its nuclear fuel procurement program. However, due to the lack of a positive response, in December 2006, the U.N. Security Council unanimously adopted Resolution 1737, which imposed sanctions on Iran by prohibiting countries in the world from conducting nuclear and missile technology transactions to Iran as well as freezing several assets in Iran.

A long series of negotiations regarding nuclear activities in Iran finally closed in July 2015, when Iran and the P5+1 countries agreed on the Joint Comprehensive Plan of Action (JCPOA) an agreement that has a term of 15 years and limits Iran's nuclear weapons development capacity. This agreement was ratified by all members of the U.N. Security Council on July 20, 2015, marked by the issuance of Resolution 2231, and means Iran is required to comply with the provisions in the JCPOA, which the IAEA will then verify. In return, Iran will be subject to waivers and even lifting economic sanctions related to Iran's nuclear program from the $\mathrm{P} 5+1$ countries. 
The JCPOA is often a benchmark for the success of multilateral relations in the anarchism of the international system, especially in the field of nuclear non-proliferation, to reduce conflicts on a global scale (Arms Control Association, 2020). On the other hand, the Middle East Region views that the JCPOA agreement will legitimize Iran's nuclear program and further legitimize Iran's influence and power in the region. Likewise, in the domestic U.S., as one of the countries that were influential in reaching the agreement, there seems to be a fragmentation of views the Democratic Party, with a majority that supports the Obama administration, has agreed to the JCPOA. In contrast, most Republicans have criticized and rejected it (Arms Control Association, 2020).

One Republican politician who has repeatedly criticized him is Donald Trump. Since becoming a U.S. presidential candidate in 2016 has declared that he will investigate the worst deal ever and has promised to leave the JCPOA if he is elected U.S. President (Lorber, 2016; Jovan, 2021). Trump, who was finally elected in November 2016 as the 45th U.S. President, insisted on campaigning that the JCPOA was the worst deal ever and wanted renegotiation, namely through the re-imposition of all sanctions that had been eased in the JCPOA. However, allies on the European side in the P5+1 indicated their rejection of the JCPOA's renegotiation efforts. Even United States' allies in Europe complained that the U.S. had no right to withdraw from the JCPOA (Arms Control Association, 2020; Jovan, 2021; Schwammenthal, 2018).

If based on the IAEA monitoring report on Iran, which remains on track to comply with the JCPOA implementation (Arms Control Association, 2020), on the other hand, Iran often reaps controversy from a number of its ballistic missile development activities. Until exactly 18 months in Trump's term or on May 8, 2018, the U.S. withdrew unilaterally from the JCPOA agreement. The U.S. claim justifies this action that Iran has supported the terrorism movement and the development of ballistic missiles (Nuclear Threat Initiative, 2020), which often leads to destabilization in the Middle East region by triggering conflict, terror, and chaos (Paramasatya \& Wiranto, 2019, p. 300).

The attitude and policies of the U.S. administration's unilateralism during the Trump leadership that withdrew from the JCPOA agreement were considered to have affected the political, economic, and international security fields based on global governance. Politically, Trump's policy of withdrawing the U.S. from the JCPOA contradicts the previous President's policies, Barack Obama. Besides that, Trump's policy is considered not to comply with the agreement initiated by United States' allies, such as Germany, France, and Britain. These three countries are even disappointed with Trump's decision (Ratnasari, 2018). For U.S.'s allies, the United States' exit from the JCPOA causes insufficient effective control over Iran, especially those related to Iran's political power in the Middle East Region, where Iran is perceived to be involved in various conflicts in the region (Paramasatya \& Wiranto, 2019). From an international security perspective, former U.S. President Barack Obama also said that without the JCPOA, the U.S. would lose to a nuclear-armed Iran or another war in the Middle East (Ratnasari, 2018).

This research will analyze the Collapse of Global Governance: When the U.S. Leaves the Joint Comprehensive Plan of Action (JCPOA). Studies related to global governance can be seen from its historical sociology that emerged from the Gramscian and Weberian approaches. The concept is currently represented by the prominent view put forward by Murphy, where global governance is a study of the role of international organizations concerning the evolution of capitalism (Hewson, 1996). Global governance is also related to political sociology, which shows globalization and contemporary politics related to cultural issues, social structures, and 
democratic social action (Nash, 2010). One of the things described from global governance is the existence of a world order, which will raise a new question about the politics of global governance? What can we expect from them? What's their agenda? (Müller, 2005).

\section{Literature Review}

\subsection{Global Governance}

Global governance is a relatively new study in politics and international relations. The existence of global governance is seen along with globalization. It is also part of globalization itself, both in terms of economy, politics, international relations systems, to the model of global community interaction in terms of certain interests that state institutions and non-state actors carry out.

Global governance is different from good governance. Global governance regulates without sovereign authority and relationships that transcend national boundaries. Global governance conducts internationally what governments do in their countries (domestic) (Finkelstein, 1995). Global governance is also seen as an effort or way to solve social and political problems that exceed the capacity of the state to handle them independently so that they can be resolved in an orderly and reliable manner (Weiss \& Gordenker, 1996).

Governance and government also have fundamental differences in understanding the main concepts in global governance. Government can work in a state of weak legitimacy, while governance can only work when the majority accepts its presence (Rosenau \& Czempiel, 1992).

In essence, global governance is a government without a government called "governance without government" (Rosenau \& Czempiel, 1992). Issues that the state cannot handle independently require more than one party, both the state and international organizations (nonstate), to address common issues based on common interests (Commission on Global Governance, 2020).

From the previous definitions, it can be concluded that the global governance or global governance actors are divided into state and non-state actors. These actors include intergovernmental organizations, Intergovernmental Organizations (IGOs), civil society representatives, international economic and financial actors, states, and informal groups (Francois, 2009).

\subsection{Global Polarization}

Polarization in the international system arises because the interests of each country, whether political, economic or security, prioritize their country. Each country will try to increase its political, economic, and security power to survive in the international system. Every country will never give up when they see the advantages of other countries so that there will be competition in increasing this power. Instead, this will become a source of new threats for other countries (Herz, 2003). In the security sector, this will create a security dilemma in which every country that feels threatened will strengthen its security. In the end, this led to the polarization of the ruling countries.

Conceptually, global polarity is a form of relations between countries in the world that is based on power and power-sharing in the international community. This polarization reflects the number of countries competing for global power. The strength that is the criterion of these countries is usually their economic strength and military strength. There are three general forms of polarity: bipolar, multipolar, and unipolar. 
Bipolar can be interpreted as a situation in which global power is in the hands of two equally powerful countries, such as the U.S. and the Soviet Union, during the cold war. Then multipolar is when more than two countries are equally strong in fighting for global power like European countries before World War I. And the last is unipolar, where there is only one country in power in the global order, or there is only one superpower like today (post-Cold War) where the U.S. is the only superpower (Haas, 1970).

Concerning the global governance phenomenon with the leaves of the U.S. from the Joint Comprehensive Plan of Action (JCPOA), it shows a tendency that global polarization in global governance is seen from the existence of a unipolar form of polarization. With it, the U.S. wants to position itself as the ruler or the party in power in the global order by creating a world order which, in his view, is ideal.

\subsection{National Interest}

National interest is one of the important points in the formulation or making of policies and decisions and attitudes towards international relations. According to Charles Beard, national interest is the basis or reason for a country (raison d'etat) contained in the goals and ambitions of a country in playing a role in international relations (Burchill, 2005). In addition, according to Theodore Couloumbis and James Wolfe, as cited in Bakry (2017), national interest will always be an important point in making predictions and prescriptions related to international behavior.

The national interest consists of four motivations, namely individuals, organizations, ideologies, and strategies (Oppenheim, 1987). Individuals are usually the leaders of the country who then form organizations that have the same interests. Then from these leaders and organizations, an ideology that is considered suitable for the country, such as liberalism or communism, will be created. In the end, from the country's individual (leader), organization, and ideology, a good strategy will be launched to achieve its national interest.

National interest also has four dimensions: economic, security, international interests, and ideology (Neuchterlein, 1976). The national interest will be based on these four dimensions: the interest to fulfill the country's economy, protect its citizens from within and outside the country, establish good and profitable relations with other countries and the international community, and implement and defend the country's ideology.

National interests will be formed through these motivations and dimensions, but each country must choose its national interests priorities from the many national interests (Clinton, 1986). Referring to some of these concepts, each country will try to protect or maintain its national interests during a global governance trend. This is to minimize the significant reduction of the role and existence of the state in the governance of international relations.

\section{Research Methodology}

This study uses a qualitative method that explores and discusses the failure of the global governance system in the Iran nuclear agreement or known as the Joint Comprehensive Plan of Action (JCPOA). In this qualitative study, the analytical procedure uses secondary data taken from journals, media, and literature related to the Iran nuclear agreement and previous analyses that discussed the United States' exit from the JCPOA agreement. Based on the search for the secondary data, there was some information regarding the background or motives and the impact of the United States' exit from the JCPOA, which also had implications for the collapse of global governance built before the Trump administration. 
Furthermore, this qualitative research is non-interactive, which does not collect data from direct interaction with humans as a data source, but rather collects data and identifies and analyzes data subjectively to synthesize data through these secondary data sources. Then, in this non-interactive qualitative research, we use conceptual, historical, and policy analysis. The various data that have been collected are then validated using source triangulation techniques, after which we use the filtered data as material for the analysis process. The analysis technique is done by arranging the order of the data, organizing the data into a pattern, category, and basic description. In this process, the data is simplified to be easier to read and interpret to explore broader, detailed, and in-depth information.

\section{Results and Discussion}

\subsection{Background of the United States Leave the JCPOA}

Trump announced the U.S. withdrawal from the Joint Comprehensive Plan of Action (JCPOA) or the Iran nuclear agreement on Tuesday, May 8, 2018, at the White House, Washington, D.C. In his speech, Trump said, "we cannot prevent Iran's nuclear bombing under the weathered structure of the current agreement" (Yasinta, 2018). In justifying his decision, Trump revealed, "I am announcing today that the United States will withdraw from the Iran nuclear deal" (BBC News, 2019). With the U.S. pulling out, Trump also announced that he would reimpose sanctions on Iran's oil sector, which had been lifted as part of the agreement.

The U.S. withdrawal through Trump cannot be separated from U.S. national interests and Trump's ambitions. In a report by The Commission on America's National Interests entitled "America's National Interest," United States has five vital national interests, namely preventing the threat of biological, chemical, and nuclear weapons attacks against the U.S. and its military forces abroad, ensuring the survival of U.S. allies in establishing a cooperative international system, ensure the stability of the global system, prevent conflicts between major countries on U.S. borders, and establish good relations with countries that can become strategic enemies of the U.S., such as Russia and China (Belfer Center for Science and International Affairs, 2000).

It is only natural that the U.S. plays a very important role and interferes in Iran's nuclear development affairs with the U.S. national interest. The U.S. has long suspected Iran to develop nuclear weapons of mass murder. However, Iran has denied this and said that they are developing nuclear technology only to ensure security and peace and not be used as weapons of mass murder (Schwammenthal, 2018; Mousavian \& Mousavian, 2018).

The development of nuclear technology in Iran has been going on for quite a long time, starting in 1956. The U.S. has become one of Iran's partners in developing nuclear technology. However, this cooperation has foundered since Iran's Islamic Revolution in 1979. Even though cooperation with the U.S. ended, the development of nuclear technology in Iran continued. This made the U.S. worried, so it tried to pressure Iran not to continue with the nuclear project. The U.S. had imposed economic sanctions on Iran and made the Iranian economic sector experience a decline. Even so, Iran's politics and government remain strong so that the development of Iran's nuclear technology is still ongoing. Hence, the U.S. and the P5+1 countries entered into an agreement with Iran in 2015 called The Joint Comprehensive Plan of Action (JCPOA). However, in 2018, Donald Trump decided to withdraw from the agreement unilaterally.

Trump has been actively raising this issue since his campaign period. Trump considers that the Iran nuclear agreement or JCPOA is the worst U.S. mistake. In his campaign, Trump promised to repair the JCPOA agreement or leave the agreement (Lorber, 2016), and in the end, when Trump was elected President of the U.S., he proved this by leaving this agreement in 2018 
because Iran refused the terms given by Trump. Trump's firm and strong thinking about rejecting the JCPOA agreement were evidenced by his dismissal of secretary of state Rex Tillerson, who was considered to have different views with Trump on the Iranian nuclear issue. The Central Intelligence Agency (CIA) director, Mike Pompeo, replaced this position, strongly criticizing the Iran nuclear agreement. Trump also fired U.S. National Security Adviser McMaster and several other officials because of differing views on this matter (McLaughlin, 2018).

According to Schwammenthal (2018) and Simon (2018), there are three main factors in the U.S. withdrawal from the JCPOA agreement by Trump, namely:

1) Prevent Iran, which it considers the main supplier of terror countries, from enriching nuclear weapons and uranium. (Counter-terrorism has been a foreign policy regular on the U.S. national security agenda since the $9 / 11$ terrorist attacks).

2) Provide high-level economic sanctions to Iran and countries that assist Iran in its nuclear development.

3) Consider the return of billions of dollars of frozen Iranian assets.

In addition to the three things above, the United States has the principles and foundations of foreign policy that it has held for a long time: upholding the values of democracy, human rights, and eradicating terrorism. So that this is also the main point of the U.S. withdrawal from the JCPOA agreement because Iran is considered the main sponsor of terrorism activities in the Middle East. Another U.S. national interest derived from withdrawing from the JCPOA agreement is bilateral relations with Israel and Saudi Arabia. Israel and Saudi Arabia are among the countries that want the JCPOA agreement canceled, hoping for more pressure on Iran to stop its nuclear activities. Moreover, Trump has promised Israel to stop Iran's nuclear development program. Israel's desire for the U.S. to leave the JCPOA can be seen from Benjamin Netanyahu's statement at the American Israel Public Affair Committee (AIPAC) meeting who presented Iran's nuclear dangers based on stolen Iranian documents by Israeli intelligence (Nuclear Threat Initiative, 2020).

In addition, Trump wants to show his political stance by withdrawing from the Iran nuclear agreement. Withdrawing from the JCPOA has been Trump's promise since the campaign period. This realization shows that Trump is a politician who keeps his promises, unlike other leaders who can only give empty campaign promises. The U.S. withdrawal from the JCPOA agreement is also based on Trump's idea of "Make America Great Again". According to Trump, this agreement has harmed America and has benefited Iran. Trump considers this equivalent to the U.S. assisting Iran in developing nuclear weapons.

With the withdrawal of the U.S. from the JCPOA agreement, there are at least five advantages to the U.S. national interest, namely: preventing the strengthening of the Iranian economy; weakening Iran's hegemony in the Middle East; preventing Iranian ballistic missiles from developing; maintaining good relations with Saudi Arabia and Israel; and image Trump as a leader who keeps his promises.

In essence, the U.S. has two national interests regarding Iran's nuclear development, namely defense interest and world order interest. However, under Trump's leadership has more extreme ambitions to eradicate the Iranian regime. 


\subsection{Impact of U.S. Leaves the JCPOA}

With the release of the U.S. from the Iran nuclear agreement or JCPOA, of course, it will have various good impacts for the U.S., countries that the JCPOA binds, and even internationally. At least three main sectors are affected: politics, economy, and security.

\subsubsection{Politics}

In terms of politics, especially the U.S., the most likely impact is that the U.S. will have a bad image in the eyes of the supporters of the JCPOA agreement and international organizations (non-state). Those who support this agreement include the United Nations and the IAEA. Besides that, political and diplomatic relations between the U.S. and Iran will deteriorate. Worse things might happen, which the international community, both state and non-state organizations, will think twice about collaborating with or entering into an agreement with the U.S. History records that the U.S. has left the JCPOA agreement unilaterally. However, this has minimal possibility because of the U.S. position as a superpower that certainly has strong power.

The Middle East region may feel the political impact. The Middle East is where Iran, Israel, and Saudi Arabia are located. With the U.S. exit from the JCPOA and the re-imposition of sanctions against Iran, geopolitical tensions will arise in the Middle East.

For international politics, the U.S.'s exit from the JCPOA will result in tensions, creating two camps between countries in the world, namely countries that criticize the U.S. for unilaterally exiting the Iran nuclear agreement and countries that support the U.S. In addition, this makes countries with bilateral and multilateral relations with Iran wary and take uncertain political steps because there are two considerations, namely fear of U.S. sanctions and worsening relations with Iran.

International politics will also be increasingly centered, with the U.S. at its center. Most global issues, including the JCPOA, are driven by the U.S. as the main axis. This causes the U.S. hegemony in the international world to be even more significant since the world's political and economic system has become unipolar. At the same time, global governance is expected to break unipolar with common interests issues that are multipolar and has failed to be proven by the unilateral departure of the U.S. from the JCPOA.

\subsubsection{Iran and the World Economy}

After signing the JCPOA agreement, Iran's economy looks quite good because of the easing of sanctions applied. For Iran, resources in the form of oil are the main commodity for export - which before the JCPOA, Iran's oil exports had decreased, but it could improve in 2016, after the JCPOA agreement.

After the U.S. exit from the JCPOA, it can be seen that since mid-2018, Iran's oil production and exports have decreased significantly and continuously until 2019 (BBC News, 2019) to a production figure of $1,705,400$ barrels per day, with an oil demand of $1,837,800$ barrels per day, and exports of 651,100 barrels per day (OPEC, 2020). According to OPEC data reported by BBC News, Iran had experienced a peak in its oil production of 3.8 million barrels per day and exported 2.3 million barrels per day. In April 2019, Iran's oil exports fell by an average of a million barrels per day and affected the Iranian government's revenue which was reduced by billions of dollars. Two months later, Trump wanted maximum pressure on Iran and declared his "intentions to zero Iran's oil exports" - by October 2019, the decline in Iran's oil exports was even more significant to 260,000 barrels per day. 
Other data from TankerTrackers, which tracks oil shipments and storage, says Iran's oil exports have fallen by more than 2.5 million barrels per day since the U.S. departed from the JCPOA. However, Iran is already starting to show signs of increasing its exports in August 2020, although it varies between 300,000-750,000 barrels per day, and in September 2020, varying between 400,000-1,500,000 barrels per day - indicating that it is still difficult to track shipments of Iranian oil exports. This tracking difficulty is also due to Iran's cessation of supplying products to the Organization of the Petroleum Exporting Countries (OPEC) since U.S. sanctions were again imposed (Sharafedin \& Lawler, 2020). Data from TankerTracker itself cannot be validated with certainty, considering that the tracking of ships shipping oil exports from Iran cannot be detected. There has been no official confirmation regarding Iranian oil production and exports in 2020.

\section{Iran's oil output}

Production in millions of barrels per day

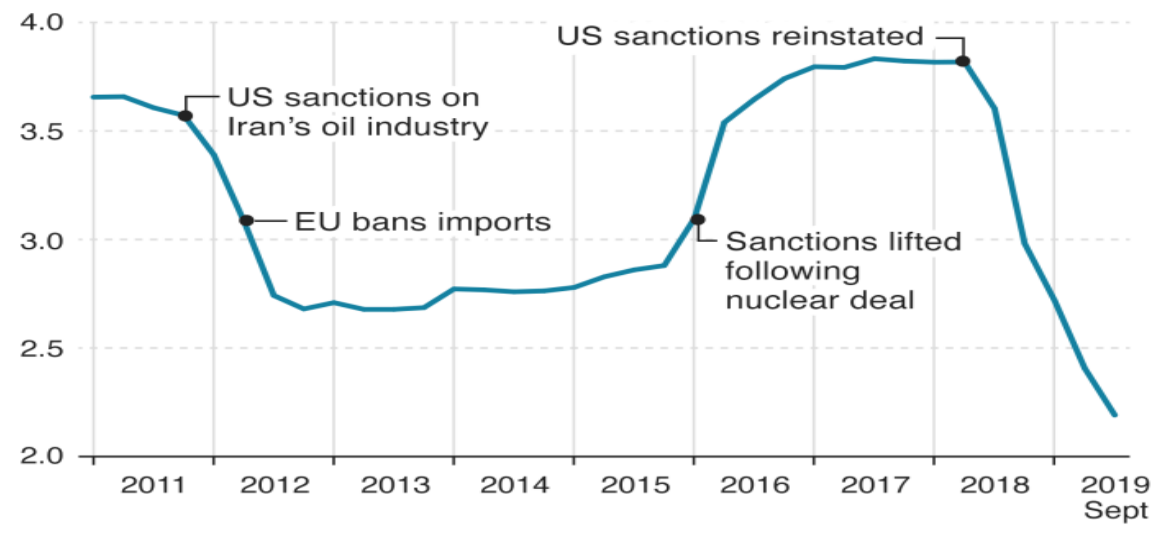

Data to September 2019

Figure 1. Iran's oil production 2011-2019

Source: OPEC in BBC News (2019)

\section{Iran brent crude exports}

Exports in millions of barrels per day

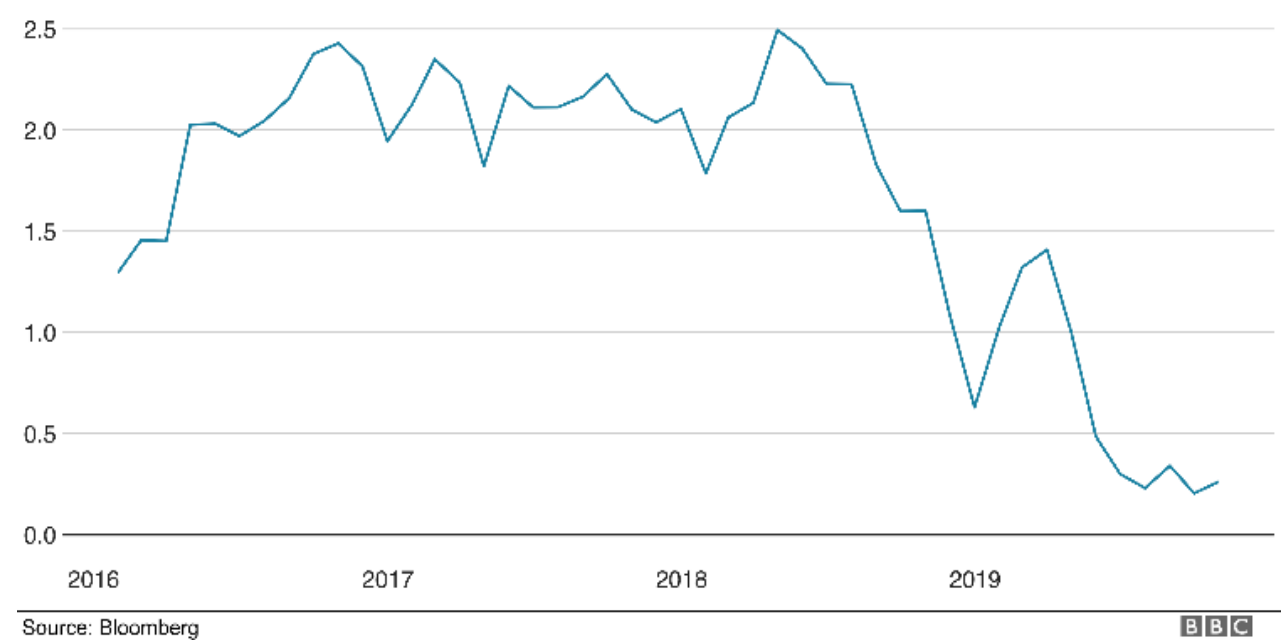

Figure 2. Iran Oil Exports 2015-2019

Source: Bloomberg in BBC News (2019) 
As a result of the Trump administration's decision to leave the JCPOA agreement and reimpose economic sanctions on Iran, American companies with ties to Iran must terminate their contracts within 180 days of the United States' decision to no longer be bound by the JCPOA, as well as the imposition of secondary sanctions to the Central Bank of Iran imposed by the U.S. Treasury (BBC News, 2017).

The impact on Iran itself is that the production and export of oil commodities have decreased significantly, affecting Iran's economic growth. According to a World Bank report, Iran experienced an accelerated recession and inflation throughout 2019-2020, given the tightness of U.S. sanctions, plus the impact of the COVID-19 pandemic. It was identified from the further weakening of GDP growth, shrinking jobs (24.3 million) workers in 2019 fell to 1.5 million workers in 2020), the increase in domestic production prices, to the depreciation of the Iranian rial against the U.S. dollar (BBC News, 2019; World Bank, 2020).

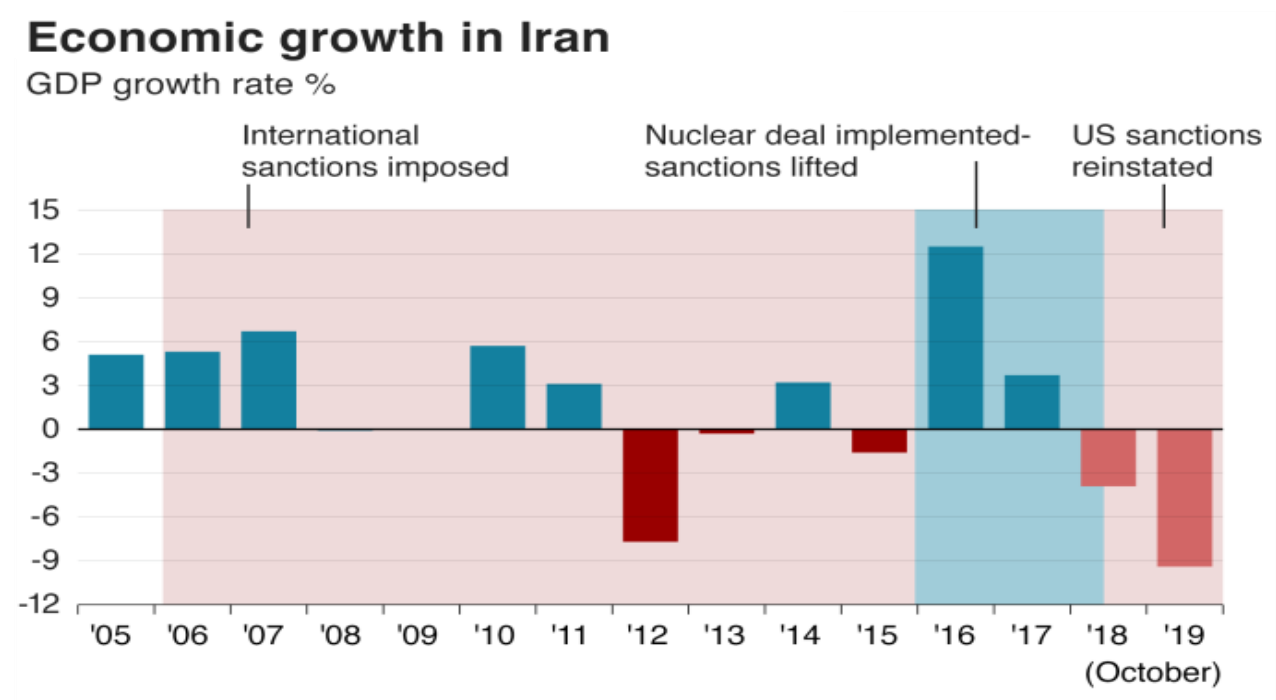

Source: Central Bank of Iran, IMF

BIBC

Figure 3. Iran's economic growth (2005-2019)

Source: Central Bank of Iran and IMF in BBC News (2019)

\section{Iran's currency has hit record lows recently}

Number of Iranian rials to one US dollar at unofficial market rate 0

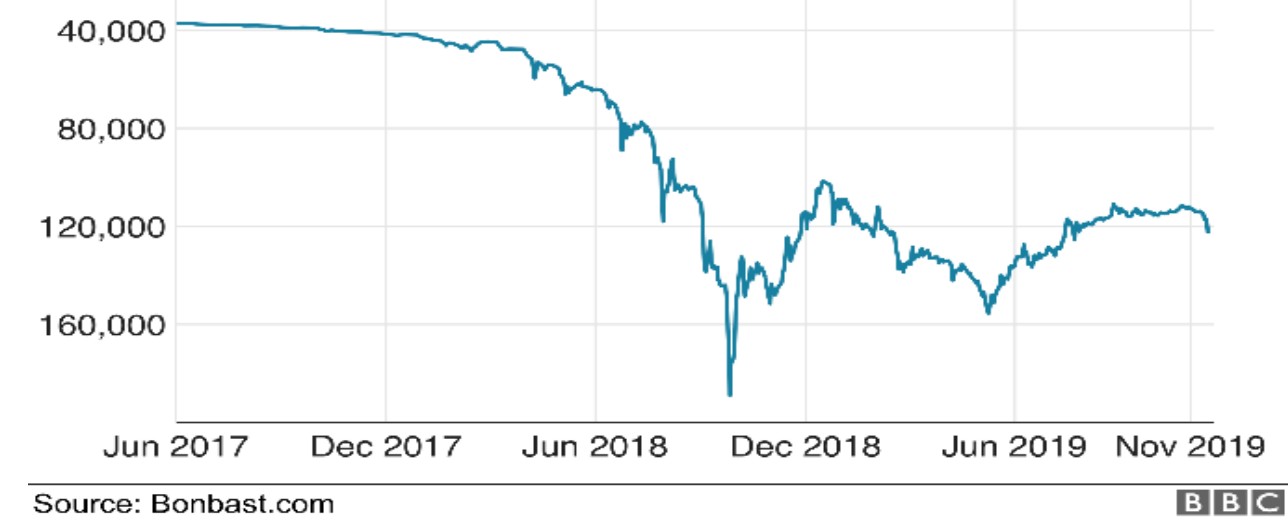

Figure 4. Iranian rial exchange rate against U.S. dollar (2017-2019) Source: Bonbast in BBC News (2019) 
Another view states that the U.S. economy does not influence the Iranian economy because of the less intense trade between Iran and the U.S. after 1979. Iran's economic condition is not so much affected by the U.S. business sector (Palamar, 2018). However, a significant economic impact is when the U.S. imposes a policy of extraterritorial sanctions, one of which is for foreign companies from any country that does business with Iran (Palamar, 2018). Sanctions are in the form of transactions by foreign financial institutions with central banks or financial institutions in Iran (sanctions are imposed after 180 days of rest since the U.S. exit from the JCPOA). On the other hand, can also be in the form of sales, supplies, and transfers directly or indirectly to or from Iran in the graphite market, metals, aluminum, steel, coal, to oil (The U.S. Department of Treasury, 2018).

Iran is heavily involved in the global market or economy, considering that petroleum is Iran's largest export commodity. Until 2018, Iran is known to still export to the following countries.

Table 1. Iran oil importing country in thousand barrels per day

\begin{tabular}{|l|c|c|c|}
\hline \multicolumn{1}{|c|}{ Country/Year } & $\mathbf{2 0 1 5}$ & $\mathbf{2 0 1 6}$ & $\mathbf{2 0 1 7}$ \\
\hline China & 540 & 625 & 625 \\
\hline India & 220 & 460 & 470 \\
\hline Japan & 170 & 225 & 170 \\
\hline South Korea & 115 & 280 & 360 \\
\hline Turkey & 110 & 140 & 245 \\
\hline Europe & - & 245 & 470 \\
\hline
\end{tabular}

Source: Aslan (2018, p. 14)

This linkage of other countries in energy supply may have benefited Iran in the last years before the re-imposition of U.S. sanctions. Due to economic sanctions, Iran is also experiencing a decline in oil production. It seems to have to face economic problems that affect the global market because its export market is very limited. According to Aslan (2018, p. 21), it is also concluded that U.S. sanctions have caused global companies and large-scale companies to be 'bound', there is no direct investment in Iran, and the deepening of socio-economic problems in Iran. The limitations of Iran's export market will also affect the need for oil imports from countries that are usually Iran's trading partners.

U.S. extraterritorial sanctions have also apparently caused Trans-Atlantic relations to oscillate. Countries such as France and Germany were pressured to withdraw. The Trump administration focused on when the United States withdrawal the JCPOA was related to the global economy and security. These include the intention to prevent the Iranian regime from sponsoring terrorism, enriching uranium, and reaching the threshold of a nuclear explosion, also, imposing the highest level of economic sanctions on Iran and any country that assists Iran in developing nuclear weapons or does business in Iran (Cherkaoui, 2010, p. 3).

French Finance Minister, Bruno Le Marie, responded by complaining that U.S. sanctions made the U.S. look like an "economic policeman of the planet", in line with the opinion of E.U. High Representative/Vice President Federica Mogherini criticized U.S. sanctions and stated that the JCPOA was the culmination of 12 years of diplomacy, and (JCPOA) is owned by the entire international community (Cherkaoui, 2010, p. 4). 
To a lesser extent, U.S. policies have contributed to the economic order and global trade conditions, especially Iran's national economy, including Iran's trade relations with various countries globally.

\subsubsection{Regional and Global Security}

JCPOA is often a benchmark for the success of multilateral relations in the anarchism of the international system, especially in the field of nuclear non-proliferation, to reduce conflicts on a global scale (Arms Control Association, 2020). On the other hand, the Middle East region views that the JCPOA agreement will legitimize Iran's nuclear program and further legitimize Iran's influence and power in the region.

Since the early departure of the U.S. from the JCPOA agreement, Iranian President Hassan Rouhani has reacted. He regretted the lack of U.S. commitment to the agreement. He stated that he had asked Iran's Atomic Energy Organization to start procuring uranium for its nuclear program if the JCPOA agreement no longer offered any benefits (Cunningham \& Sabbagh, 2018). JCPOA can provide a benefit or a risk: Iran's moderation and help increase the stability of the Middle East region, or it can even lead to destabilization due to the possibility of increasing competition between Iran, Saudi Arabia, and Israel. The JCPOA may strengthen nonproliferation norms worldwide or generate a race to increase security capabilities between countries in the Middle East region to match Iran's (Goldenberg et al., 2015, p. 5).

Indications of regional destabilization after the U.S. withdrawal from the JCPOA began to emerge, one of which was the return of Iran with a tough military approach and strategy. According to Behravesh (2018), Iran has emerged as a firm regional strategy, seen as an attempt to adapt to the international environment. It is known from Mike Pompeo, as the U.S. Secretary of State, Iran is known to have launched the attack, which took place near the export port of Fujairah on the coast of the Arab Emirates and across the Strait of Hormuz. Iran briefly denied U.S. claims that blamed the attack on Iran and asked for evidence. This caused tension considering Iran threatened to close the Strait of Hormuz in July 2018 if the U.S. blocked its oil exports (Tempo, 2018).

Furthermore, on September 14, 2019, it was reported that attacks from drones and cruise missiles paralyzed the Saudi Arabian Oil Company (Aramco) facilities in Abqaiq, Saudi Arabia (Arms Control Association, 2020). The Trump administration seemed to immediately point to Iran as the party responsible for the attack on Aramco, after U.S. intelligence discovered that Iran was involved in the attack - as did Saudi Arabia's claims through its officials that Iran attacked Saudi oil infrastructure on September 14, 2019. On September 23, 2019, a few days later, the United Kingdom, France, and Germany also released statements condemning the September 14 attacks by Iran on Saudi oil facilities at Aramco (Arms Control Association, 2020).

According to Ahmadian, a researcher at the Belfer Center for Science and International Affairs, Trump's policy wants to isolate Iran and place it under the limelight as a threat to international peace and security to rid Tehran of the benefits that might be obtained from the JCPOA (Belfer Center for Science and International Affairs, 2018).

In the security sector, the impact of the U.S. exit from the JCPOA agreement has caused tension in U.S. relations with Iran, which further affected the reaction from Iran with its defense "show" and impacted the Middle East regional stability. The security stability of the Middle East itself is quite important here in the international system, considering that the Middle East is a strategic world trade route. 
Such as the Gulf of Hormuz Strait, for example, which is the route through which oil tankers amount to around 17.2 million barrels per day or one-sixth of the global oil supply exported by OPEC member countries: Iran, Saudi Arabia, Iraq, United Emirates, Kuwait, and Qatar (Wulan, 2020), to various countries around the world. Taking lessons from what has happened before, Iran's significance in this strategic area needs to be considered, including how tensions between the U.S. and Iran will affect international trade, which requires security stability in this region.

\subsection{Global Governance in the JCPOA Post the U.S. exit}

Shortly after the U.S. withdrew from the JCPOA agreement, there were several notes from other international actors in responding to this unilateral U.S. action. France, Great Britain, and Germany had issued a joint statement to continue to support the JCPOA agreement, given the importance of non-proliferation efforts. French President Emmanuel Macron tweeted that France, Germany, and the United Kingdom regret the U.S. decision to leave the JCPOA. Even though a nuclear non-proliferation regime is a priority - and a tweet by Boris Johnson, the Prime Minister of the United Kingdom, stating the United Kingdom's commitment for the JCPOA to stay strong and work with all other parties involved to continue to maintain it. In an interview, French Prime Minister Jean-Yves Le Drian also states that the agreement (JCPOA) is not yet over.

The Secretary-General of the United Nations, Antonio Guterres, who consistently emphasizes that the JCPOA is a major achievement in non-proliferation, nuclear diplomacy, and contribution to regional-international peace and security, is "deeply concerned" and asks all parties to maintain the agreement (United Nations, 2018). Meanwhile, the Russian Foreign Minister also reiterated his support for the JCPOA, and responding to U.S. actions could undermine the international environmental trust in the IAEA (Reuters, 2018). Regarding the IAEA, the E.U. diplomat then said that the European Union would remain committed to continuing the full and effective implementation of this nuclear agreement (JCPOA) and trusting the IAEA's performance, competence, and autonomy, which constantly reports on the implementation of the agreement. Likewise, Russia and China are committed to maintaining the JCPOA agreement.

The head of the IAEA, Yukiya Amano, stated no indications of violations. Iran was still in compliance with the agreement, considering that IAEA inspectors were still given access to all sites and sites of Iran's nuclear development - and if the JCPOA failed, it would be detrimental to nuclear verification and multilateralism (United Nations, 2018).

Other countries that are not bound by the JCPOA agreement, such as Australia and Japan, through Prime Minister Malcolm Bligh Turnbull and Foreign Minister Taro Kono, regret the U.S. decision and hope those other countries involved will continue to maintain the agreement (Al Jazeera, 2018). Likewise, through President Erdogan's spokesman, Ibrahim Kalin, Turkey tweeted that the U.S.'s exit from the JCPOA was a risk to the world (international environment). The opposite reaction and pressure came from Saudi Arabia, the Arab Emirates, and Bahrain, which agreed with Israel in supporting the Trump administration's decision to leave the deal and reimpose economic sanctions on Iran (Al Jazeera, 2018).

Trump's decision was also emphasized by the 44th President of the U.S., Barack Obama, and the Former U.S. Secretary of State, John Kerry. Obama wrote his statement that the JCPOA is part of the U.S. national interest. In addition to restraining Iran's nuclear program significantly, the JCPOA is also a form of diplomatic success, whose supervision and 
verification can be adapted in handling bilateral relations between the U.S. and North Korea (Al Jazeera, 2018). In addition, John Kerry also claims that the Trump administration's decision is destructive to U.S. security, commitments, and risks to Israel, Iranian extremists, and the ability of subsequent U.S. administrations to draft international agreements (Al Jazeera, 2018).

Indeed, based on the policy analysis "After the JCPOA: A Game Plan for the United States", the JCPOA has represented a historic moment for U.S. foreign policy, which this agreement has not seen its significance because it will be judged on its ability to further assist the goals and U.S. interests in preventing Iran from obtaining nuclear weapons; enhancing Middle East regional stability; strengthening the non-proliferation regime, and; updating U.S. power or position on a global scale. To analyze the influence to pursue the success of U.S. goals, it will depend on U.S. policy towards the JCPOA agreement. If the implementation of this agreement is successful, it is likely to open up new lines of cooperation in halting Iran's pursuit of nuclear weapons permanently. However, if this implementation fails, the JCPOA is projected to pave the way for Iran to have nuclear weapons within 15 years or even sooner (Goldenberg et al., 2015, p. 5).

From the analysis found, global governance as an effort to solve social and political problems beyond the state's ability to handle them can be realized in nuclear weapons that cannot be resolved independently, given the high risks and threats that may arise. It is necessary to have political and adequate security to control it.

The international system's efforts to deal with it arise in the policies of international organizations such as the United Nations, which bridges the world's countries in dealing with nuclear weapons problems with the issuance of the NPT, several resolutions, to the JCPOA. The IAEA is also an agency that monitors and assesses the development and use of nuclear energy to ensure that all its activities are following international agreements.

In addition, based on the concept of global governance, which considers majority approval, it does not work in the JCPOA, considering that most parties, whether directly involved in the agreement or not, have more hope in the sustainability of the JCPOA. The U.S. withdrawal also has implications for global fragmentation - in which, politically, U.S. policy supports global polarity, and the U.S. is predicted to have unipolar power because of its ability (political capability through policy) in influencing the global economy and security sector quite significantly.

Finally, in the security sector and the impact that has been studied, it creates a security dilemma. The countries involved, especially Iran, continue to strengthen their security with repressive measures, mainly in the Middle East region, which is emerging as a threat to other countries in the world.

\section{Conclusion}

It can be seen that global governance has a fundamental weakness in its implementation. Through an analysis of the U.S. withdrawal from the Iran nuclear agreement, it can be said that the control of interests is in the hands of the U.S. Even though following the concept of global governance, namely "common interest", the Iran nuclear deal involved P5 + 1 state actors and international organizations such as the U.N. Security Council and the IAEA, and even international support, but this did not make the U.S. depressed. If it is not in line with its national interests, the U.S. can withdraw unilaterally. If so, it can be said that the U.S. is said to be a country that has power and influence. This superpower state makes countries and 
international organizations tools under the umbrella of common interests, even though the shared interests are generally drawn from their national interests.

Based on the research analysis results, the collapse of global governance when the U.S. left the Joint Comprehensive Plan of Action (JCPOA) was seen from the strong national interest of the U.S. as a superpower country. The implementation of global governance in the JCPOA is also constrained by the world's political and economic order, which appears unipolar. There is one country that shows its power in the global order.

\section{Acknowledgment}

The authors are grateful to express gratitude to those who have had the pleasure to cooperate during this research.

\section{Declaration of Conflicting Interests}

The authors have declared no potential conflicts of interest concerning the study, authorship, and/or publication of this article.

\section{References}

Al Jazeera. (2018, May 9). World leaders react to U.S. withdrawal from Iranian nuclear deal. Hassan Rouhani News | Al Jazeera. Retrieved from https://www.aljazeera.com/news/2018/5/9/world-leaders-react-to-us-withdrawalfrom-iranian-nuclear-deal

Arms Control Association. (2020, September). Timeline of Nuclear Diplomacy With Iran. Retrieved October 28, 2020, from https://www.armscontrol.org/factsheets/Timeline-ofNuclear-Diplomacy-With-Iran

Aslan, M. (2018). The Economic Consequences of the US Withdrawal from the Nuclear Deal. Ankara, Turkey: Center for Iranian Studies in Ankara.

Bakry, U. S. (2017). Dasar-dasar Hubungan Internasional. Depok, Indonesia : Kencana.

BBC News. (2017, October 13). Iran nuclear deal: Trump's speech in full. BBC News. Retrieved from https:/ / www.bbc.com/news/world-us-canada-41617488

BBC News. (2019, December 9). Six charts that show how hard US sanctions have hit Iran. BBC News. Retrieved from https://www.bbc.com/news/world-middle-east-48119109

Behravesh, M. (2018, September 24). Iran More Assertive Regionally After Trump Withdrawal From JCPOA. Retrieved from https://www.atlanticcouncil.org/blogs/iransource/iranmore-assertive-regionally-after-trump-withdrawal-from-jcpoa/

Belfer Center for Science and International Affairs. (2000). America's National Interests: A Report from The Commission on America's National Interests, 2000. Author. Retrieved from https:// www.belfercenter.org/publication/americas-national-interests-reportcommission-americas-national-interests-2000

Belfer Center for Science and International Affairs. (2018, May 16). Consequences of the U.S. Withdrawal from the JCPOA. Retrieved October 31, 2020, from https:/ / www.belfercenter.org/event/consequences-us-withdrawal-jcpoa

Burchill, S. (2005). The National Interest in International Relations Theory. Basingstoke, UK: Palgrave Macmillan. 
Cherkaoui, M. (2010, May 28). Trump's Withdrawal from the Iran Nuclear Deal: Security or Economics? Retrieved from https://studies.aljazeera.net/en/reports/2018/05/trumpswithdrawal-iran-nuclear-deal-security-economics-180510123910355.html

Clinton, W. D. (1986). The National Interest: Normative Foundations. The Review of Politics, 48(4), 495-519. https:// doi.org/10.1017/s0034670500039656

Commission on Global Governance. (2020, October 15). Our Global Neighborhood. Retrieved from https:/ / www.gdrc.org/u-gov/global-neighborhood/chap1.htm

Cunningham, E., \& Sabbagh, B. (2018, May 9). Iran to negotiate with Europeans, Russia and China about remaining in nuclear deal. Retrieved October 29, 2020, from https://www.washingtonpost.com/world/middle_east/iran-prepared-for-allscenarios-if-trump-nixes-nuclear-deal-officials-say /2018/05/08/531047a0-5241-11e8a6d4-ca1d035642ce_story.html

Finkelstein, L. S. (1995). What Is Global Governance? Global Governance: A Review of Multilateralism and International Organizations, 1(3), 367-372. https:/ / doi.org/10.1163/19426720-001-03-90000007

Francois, R. (2009, January). World Governance Index: Why Should World Governance Be Evaluated, and for What Purpose? Retrieved from Forum for a new World Governance: http:/ / www.world-governance.org/

Goldenberg, I., Rosenberg, E., Golov, A., Heras, N., Maruyama, E., \& Hellman, A. (2015). After the Joint Comprehensive Plan of Action: A Game Plan for the United States. Washington: Center for a New American Security. Retrieved from http:/ / www.jstor.org/stable/resrep06378

Haas, M. (1970). International Subsystems: Stability and Polarity. American Political Science Review, 64(1), 98-123. https:/ / doi.org/10.2307/1955616

Herz, J. H. (2003). The Security Dilemma in International Relations: Background and Present Problems. International Relations, 17(4), 411-416. https://doi.org/10.1177/0047117803174001

Hewson, M. (1996). Review: Historical Sociology of Global Governance. Review of International Political Economy, 3(1), 186-193.

Jovan, C. V. (2021). The United States Unilateral Withdrawal from the Restrictions of Iran's Nuclear Program in JCPOA 2015 Under International Law. Padjadjaran Journal of International Law, 4(2), 247-264. https:/ / doi.org/10.23920/pjil.v4i2.414

Kementerian Luar Negeri Republik Indonesia. (2019, April 7). Perlucutan Senjata dan Nonproliferasi Senjata Pemusnah Massal. Retrieved October 31, 2020, from Kementerian Luar Negeri Republik Indonesia: https:/ / kemlu.go.id/portal/id/read/90/halaman_list_lainnya/perlucutan-senjata-dannon-proliferasi-senjata-pemusnah-

massal\#: :text=Traktat\%20Nonproliferasi\%20Nuklir\%20(NPT)\%20adalah,bahan\%20nuk lir\%20untuk\%20tujuan\%20damai.

Lorber, E. B. (2016, August 9). President Trump and the Iran Nuclear Deal. Retrieved from https:/ / foreignpolicy.com/2016/11/16/president-trump-and-the-iran-nuclear-deal/

Mardani, N., \& Hooshmand, M. M. (2016). JCPOA; A Dialectical Paradigm of Treaty and Other International Instruments. Journal of Politics and Law, 9(3), 70. https:/ / doi.org/10.5539/jpl.v9n3p70

McLaughlin, E. (2018, March 13). Tillerson's support for Iran deal helped get him fired, but Mattis shares his views. ABC News. Retrieved from 
https:/ / abcnews.go.com/Politics/tillersons-support-iran-deal-helped-fired-mattisshares/story?id=53712207

Mousavian, S. H., \& Mousavian, M. M. (2018). Building on the Iran Nuclear Deal for International Peace and Security. Journal for Peace and Nuclear Disarmament, 1(1), 169-192. https:/ / doi.org/10.1080/25751654.2017.1420373

Müller, P. S. (2005). Politicians of Global Governance. CONfines Relacion, 1(1), 51-66. Retrieved from http://www.scielo.org.mx/scielo.php?script=sci_arttext\&pid=S187035692005000100003

Nash, K. (2010). Contemporary Political Sociology: Globalization, Politics and Power. West Sussex: Wiley-Blackwell.

Neuchterlein, D. E. (1976). National Interest and Foreign Policy: A Conceptual Framework for Analysis and Decision Making. Cambridge: Cambridge University Press.

Nuclear Threat Initiative. (2020, June 7). Nuclear. Retrieved October 28, 2020, from https://www.nti.org/area/nuclear/

OPEC. (2020). Iran facts and figures. Retrieved October 31, 2020, from https://opec.org/opec_web/en/about_us/163.htm

Oppenheim, F. E. (1987). National Interest, Rationality, and Morality. Political Theory, 15(3), 369389. https:/ / doi.org/10.1177/0090591787015003006

Palamar, S. (2018, May 11). Trump's Iran Policy Will Have Global Economic Consequences. Retrieved November 1, 2020, from https://www.cigionline.org/articles/trumps-iranpolicy-will-have-global-economic-consequences/

Paramasatya, S., \& Wiranto, S. (2019). Konfrontasi Amerika Serikat dan Iran dalam Joint Comprehensive Plan of Action (JCPOA). Jurnal Hubungan Internasional, 12(2), 297. https:/ / doi.org/10.20473/jhi.v12i2.14047

Ratnasari, Y. (2018, May 9). AS Keluar dari Perjanjian Nuklir Iran, Trump: Kesepakatan Itu Fiksi. tirto.id. Retrieved from https://tirto.id/as-keluar-dari-perjanjian-nuklir-irantrump-kesepakatan-itu-fiksi-cJ7x

Reuters. (2018, May 8). Russian foreign ministry says disappointed by Trump's Iran decision. U.S. Retrieved from https:/ / www.reuters.com/article/instant-article/idUKKBN1I933R

Rosenau, J. N., \& Czempiel, E.-O. (1992). Governance Without Government: Order and Change in World Politics. Cambridge and New York: Cambridge University Press.

Schwammenthal, D. (2018). Europe, the US and the Iran deal: The need to resolve transatlantic $\begin{array}{llll}\text { disagreements. } \quad \text { European } & \text { View, }\end{array}$ https:/ / doi.org/10.1177/1781685818808713

Sharafedin, B., \& Lawler, A. (2020, September 25). Iran's oil exports jump in September defying sanctions: TankerTrackers. U.S. Retrieved from https://www.reuters.com/article/usiran-oil-exports-idUSKCN26G1VA

Simon, S. (2018). Iran and President Trump: What Is the Endgame? Survival, 60(4), 7-20. https:/ / doi.org/10.1080/00396338.2018.1494975

Tempo. (2018, July 24). Jenderal Iran Siap Tutup Selat Hormuz Sesuai Perintah Rouhani. Tempo. Retrieved from https://dunia.tempo.co/read/1110132/jenderal-iran-siap-tutup-selathormuz-sesuai-perintah-rouhani

The U.S. Department of Treasury. (2018, June 27). JCPOA Wind-down Frequently Asked Questions. Retrieved from https://www.treasury.gov/resourcecenter/sanctions/Programs/Documents/jcpoa_winddown_faqs.pdf 
United Nations. (2018, May 10). UN chief 'deeply concerned' by US decision to exit Iran nuclear deal. UN News. Retrieved from https:/ / news.un.org/en/story/2018/05/1009172

Weiss, T. G., \& Gordenker, L. (1996). Ngos, the Un, and Global Governance. Boulder: Lynne Rienner Publishers.

World Bank. (2020, April 16). Iran's Economic Update - April 2020. Retrieved from http:/ / pubdocs.worldbank.org/en/946261554825524131/mpo-irn.pdf

Wulan. (2020, August 7). Apa Itu Selat Hormuz? (dan Mengapa Perairan Ini Sangat Penting bagi Dunia). Retrieved from https://www.matamatapolitik.com/belajar-politik-apa-ituselat-hormuz-dan-mengapa-perairan-ini-sangat-penting-bagi-dunia/

Yasinta, V. (2018, May 9). Trump: AS Keluar dari Perjanjian Nuklir Iran. Retrieved from https://www.kompas.com/internasional/read/2018/05/09/07260231/trump-askeluar-dari-perjanjian-nuklir-iran

\section{About the Authors}

1. Yusa Djuyandi obtained his Doctoral degree in International Relations from Universitas Padjadjaran, Indonesia, in 2016. The author is an Assistant Professor at the Department of Political Science, Faculty of Social and Political Sciences, Universitas Padjadjaran, Indonesia. E-Mail: yusa.djuyandi@unpad.ac.id

2. Shafa Ghaisani Salsabila Brahmantika is a student of the Political Science Study Program, Faculty of Social and Political Sciences, Padjadjaran University, Bandung, Indonesia.

E-Mail: shafa17003@mail.unpad.ac.id

3. Bima Riandy Tarigan is a student of the Political Science Study Program, Faculty of Social and Political Sciences, Padjadjaran University, Bandung, Indonesia.

E-Mail: bima18003@mail.unpad.ac.id 